\title{
TELEMETRI SENSOR GUDANG GAS LPG BERBASIS AT-MEGA 16
}

\author{
Ahmad Ikrom ${ }^{1}$, Mushlihudin ${ }^{2}$, Abdul Fadlil ${ }^{3}$ \\ 1,3Program Studi Teknik Elektro, Fakultas Teknologi Industri, Universitas Ahmad Dahlan \\ ${ }^{2}$ Program Studi Teknik Informatika, Fakultas Teknologi Industri, Universitas Ahmad Dahlan \\ Kampus III UAD, Jl. Prof. Dr. Soepomo, Janturan, Yogyakarta \\ Email: ikrom@ee.uad.ac.id, mdin@ee.uad.ac.id, fadlil3@yahoo.com
}

\begin{abstract}
Public perception of LPG gas like seeing a frightening thing for bad news one of which is fire due to a gas leak. LPG gas warehouse is now common not to use the tools that support for monitoring LPG gas storage. Internet-based modern technology often encountered because the internet has become a necessity of today's society. One of these Internet-based remote technology could encourage the public interest, because of the ease in accessing web pages and data delivery. Remotely analyzed the role of technology can help secure and warehouse monitoring of LPG gas for the delivery of data from one place to another. Presented telemetry system built using the website, which works in realtime. Designing the system uses a sensor to read the MQ-5 LPG gas and DHT-11 sensor to read the temperature and humidity. Sensor data readings displayed on the LCD $2 \times 16$ and website. The process of delivery of the sensor to computer using ENC28J60 module with RJ-45 outputs are connected to a LAN cable and localhost to build on a webserver webserver so that the data will be stored and displayed through the website in the form of sensor values, status, date, and time. Webserver built using xampp contained database to store and report the results of the reading of the data. Results sensor telemetry system warehouse LPG gas sensor using DHT-11 and MQ-5 sensor to read the content in which there are gas propane and butane. Sensor DHT-11 temperature and humidity reading. Sensor MQ-5 can read normal conditions ACD value of 1 to 251. The value of ADC Sensor DHT-11 can read a temperature of $20{ }^{\circ} \mathrm{C}$ to $51^{\circ} \mathrm{C}$, and humidity of $38 \%$ to $99 \%$. Readings can be stored in a MySQL database and reports can be created in the form of a status report, daily report, monthly report, the overall report of data
\end{abstract}

Keyword : telemetry technology; realtime; web server; module ENC28J60; database records; sensor $M Q-5$; sensor DHT-11

\begin{abstract}
Abstrak
Anggapan masyarakat tentang gas LPG seperti melihat suatu hal yang menakutkan karena kabar tak sedap salah satunya adalah kebakaran akibat gas bocor. Gudang gas LPG saat ini sering ditemui belum menggunakan alat-alat yang mendukung untuk memonitoring penyimpanan gas LPG. Teknologi moderen berbasis internet sering kali ditemui karena internet sudah menjadi kebutuhan masyarakat saat ini. Salah satunya teknologi jarak jauh berbasis internet dapat mendorong peminat masyarakat, karena kemudahan dalam mengakses halaman website dan pengiriman data. Peran teknologi jarak jauh dianalisa dapat membantu penjagaan dan monitoring gudang gas LPG untuk pengiriman data dari satu tempat ketempat lain. Sistem telemetri yang dibangun disajikan menggunakan website, yang bekerja secara realtime. Perancangan sistem menggunakan sensor MQ5 untuk membaca gas LPG dan sensor DHT-11 untuk membaca suhu dan kelembaban. Pembacaan data sensor ditampilkan pada LCD $2 \times 16$ dan website. Proses pengiriman dari sensor kekomputer menggunakan modul ENC28J60 dengan keluaran RJ-45 yang dihubungkan kabel LAN dan localhost untuk membangun webserver sehingga pada webserver data akan disimpan dan ditampilkan melalui website dalambentuk nilai sensor, status, tanggal, dan waktu. Webserver yang dibangun menggunakan xampp yang terdapat database untuk menyimpan dan melaporkan hasil pembacaan data. Hasil sistem telemetri sensor gudang gas LPG menggunakan sensor DHT -11 dan sensor MQ-5 untuk membaca gas yang didalamnya terdapat kandungan propana dan butana. Sensor DHT-11 membaca suhu dan kelembaban. Sensor MQ-5 dapat membaca kondisi normal nilai ACD 1 sampai nilai ADC 251. Sensor DHT-11 dapat membaca suhu $20^{\circ} \mathrm{C}$ sampai $51^{\circ} \mathrm{C}$, dan kelembaban $38 \%$
\end{abstract}


Jurnal IImu Teknik Elektro Komputer dan Informatika (JITEKI)

Vol. 2, No. 1, Juni2016

sampai 99\%. Hasil pembacaan dapat disimpan pada database MySQL dan dapat dibuat laporan berupa laporan status, laporan harian, laporan bulanan, laporan keseluruhan data.

Kata Kunci: Teknologi telemetri; realtime; webserver, modul ENC28J60; record database; sensor MQ-5; sensor DHT-11

\section{Pendahuluan}

Perhatian masyarakat tentang gas LPG seperti melihat suatu hal yang menakutkan, karena seringnya kebakaran yang terjadi akibat kebocoran gas LPG. Berita tentang kebakaran ini semakin marak semenjak mulainya masyarakat mengenal bahan bakar LPG untuk kebutuhan sehari-hari. Ketertarikan masyarakat semakin tinggi untuk berpindah pada bahan bakar LPG, sehingga permintaan meningkat dan para distributor kini harus menyiapkan gudang untuk menyimpan gas yang akan dipasarkan tersebut. Tentunya dalam pembuatan gudang tidak bisa sembarangan, karena gudang tersebut akan digunakan untuk menyimpan gas LPG yang akan dipasarkan [1]-[3].

Perkembangan teknologi jarak jauh ini dianalisa akan dapat membantu penjagaan dan monitoring gudang gas LPG. Teknologi jarak jauh ini sering disebut telemetri. Telemetri di artikan dari kamus besar bahasa Indonesia adalah mengukur dari jarak jauh. Sistem telemetri yang perlu dibuat juga harus dilengkapi dengan database, karena pada pengukuran ini perlu adanya sebuah record atau laporan yang dapat memberikan informasi pada pengukuran gudang gas yang menggunakan sistem telemetri, dan dapat membri laporan harian dan bulanan, bahkan laporan keseluruhan data [4]-[6].

\section{Landasan Teori}

\subsection{Liquefied Petrolium Gas (LPG)}

Suatu bahan kimia yang terdiri dari bahan utama propana dan butana, selain itu ada beberapa kandungan yang lain dengan pesentase sedikit yaitu hidrokarbon dan beberapa fraksi C2 yang lebih ringan dan C5 yang lebih berat. Dari gabungan tersebut Ipg memiliki kandungan beberapa senyawa dalam penulisannya yaitu hidrokarbon propana $(\mathrm{C} 3 \mathrm{H} 8)$ dan butana $(\mathrm{C} 4 \mathrm{H} 10)$ dengan komposisi $30 \%$ propana dan $70 \%$ butana. Gas LPG saat ini menjadi bahan yang di programkan oleh pemerintah untuk menanggapi kelangkaan bahan bakar minyak tanah yang sebelumnya menjadi bahan pokok utama untuk memasak [2].

\subsection{Sensor $M Q-5$}

Sensor MQ-5 ini mendeteksi konsentrasi gas yang mengandung propana dan butana (LPG), Natural gas dan town gas, serta sensifitas rendah dalam membaca asap rokok dan alkohol dengan output tegangan analog. Sensor dapat mengukur konsentrasi gas dan asap dari 300 sampai 10.000 sensor ppm.

\subsection{Sensor DHT-11}

Sensor yang sensitif atau sensor yang digunakan untuk membaca besaran suhu dan kelembaban dalam satu chip sensor. Sensor DHT-11 memiliki 4 kaki memiliki fungsi masing-masing, namun yang digunakan hanya 3 pin.

\subsection{Mikrokontroler AT-MEGA16}

Mikrokontroler adalah sebuah sistem komputer lengkap dalam satu serpih (chip). Mikrokontroler lebih dari sekedar sebuah mikroprosesor karena sudah terdapat atau berisikan ROM (Read-Only Memory), RAM (Read-Write Memory), beberapa bandar masukan maupun keluaran, dan beberapa peripheral seperti pencacah/pewaktu, ADC (Analog to Digital converter), DAC (Digital to Analog converter) dan serial komunikasi. Secara umum mikrokontroler AVR dapat dapat dikelompokkan menjadi 3 kelompok, yaitu keluarga AT90Sxx, ATMega dan ATtiny. Pada dasarnya yang membedakan masing-masing kelas adalah memori, peripheral, dan fiturnya Seperti mikroprosesor pada umumnya [4], [7], [8].

\subsection{Pemrograman Mikrokontroler}

Proses pemrograman mikrokontroler diawali dengan menulis program sumber (source code) baik dalam assembly, C maupun basic. Source code kemudian di compile dan menghasilkan kodekode yang dapat dimengerti oleh mikrokontroler yaitu menghasilkan hasil compiler .hex, (format *.hex).Pemrograman menggunakan bahasa $C$ akan lebih mudah, karena bahasa yang digunakan lebih mudah dipelajari sekaligus diaplikasikan dalam hal ini khususnya. Karena untuk memprogram sistem ini diperlukan program yang cukup kompleks [4], [7], [8]. 


\subsection{LCD (Liquid Crystal Display)}

Liquid Crystal Display adalah suatu jenis media tampilan yang menggunakanLiquid CrystalDisplay sebagai penampil utama. LCD yang digunakan yaitu tipe LMB162A merupakan modul LCDdengan tampilan $2 \times 16$ karakter (2 baris $\times 16$ kolom) dengan konsumsi daya rendah, sekitar $5 \mathrm{~V}$ DC. Modul tersebut dilengkapi dengan mikrokontroler yang didesain khusus untuk mengendalikan LCD, sehingga memudahkan melakukan koneksi dengan mikrokontroler [9].

\subsection{Xampp}

XAMPP merupakan paket PHP dan MySQL berbasis open source, yang digunakan sebagai alat pembantu pengembangan aplikasi berbasis PHP. XAMPP mengombinasikan beberapa paket perangkat lunak berbeda ke dalam satu paket (Riyanto,2010:1). Di dalam Paket XAMPP terdapat tiga paket penting yaitu Apache sebagai web server, PHP sebagai bahasa pemrograman dan MySQL sebagai database. Apache adalah server web (web server) yang dapat dijalankan di banyak sistem operasi [10].

\subsection{PHP (Hypertext Preprocessor)}

suatu bahasa pemrograman yang difungsikan untuk membangun suatu website dinamis. PHP menyatu dengan kode HTML, maksudnya adalah beda kondisi. HTML digunakan sebagai pembangun atau pondasi dari kerangka layout web, sedangkan PHP difungsikan sebagai prosesnya sehingga dengan adanya PHP tersebut, web akan sangat mudah di-maintenance. PHP berjalan pada sisi server sehingga PHP disebut juga sebagai bahasa Server Side Scripting. Artinya bahwa dalam setiap/untuk menjalankan PHP, wajib adanya web server [10][11].

\subsection{MySQL}

Secara umum, database berfungsi sebagai tempat atau wadah untuk menyimpan, mengklasifikasikan data secara prefosional. MySQL bekerja menggunakan SQL Language (Structure Query Language). Itu dapat diartikan bahwa MySQL merupakan standar penggunaan database di dunia untuk pengolahan data [10].

\subsection{Module ENC28J60}

Module ethernet menggunakan ENC28J60 yang dapat digunakan untuk berkomunikasi dengan jaringan LAN maupun WAN. Module ENC28J60 dapat diprogram dengan menggunakan library yang mendukung modul ENC28J60, salah satu contohnya yaitu "ethercard"yangdapatdiunduh secara gratis. Library EtherCard merupakan sebuah jembatan/driver untuk dapat berkomunikasi dengan chip ENC28J60.

\subsection{Kabel UTP (Unshielded Twisted Pair)}

Kabel sebagai media transmisi dalam jaringan Local Area Network atau LAN. Kabel UTP termasuk kabel yang tidak memiliki pelindung dan memiliki rangkaian kabel yang saling terpilin satu dengan lain. Keberadaan kabel UTP membuat antar jaringan komputer dapat terhubung melalui LAN. Secara umum, kabel UTP terdiri dari delapan bagian, Empat buah kabel UTP terpilin menjadi satu dan sepasang kabel UTP lainnya dihubungkan untuk menerima dan mengirim antar jaringan komputer.

\section{Metode Penelitian}

\subsection{Alat dan Bahan Penelitian}

\subsubsection{Bahan penelitian :}
a. Sensor MQ-5 dan DHT-11
b. Rangkaian minisistem
c. Rangkaian catu daya
d. LCD display.
e. Modul Ethernet.
f. Kabel UTP
g. Gas LPG
h. Es Batu, Hair dryer, dan spray

\subsubsection{Alat Penelitian}

Perangkat Keras :

a. Komputer Toshiba : Prosessor Core i3 $2.50 \mathrm{GHz}$, RAM $2 \mathrm{~GB}$, Harddisk $500 \mathrm{~GB}$, dan VGA Intel HD Graphics 4000.

b. Multimeter, Obeng Set, Downloader. 

Perangkat Lunak :
a. Code Vision AVR
b. Prog ISP
c. Xamps dan Browser

\subsection{Perancangan Sistem}

Ada dua tahap dalam perancangan sistem yaitu perancangan hardware dan perancangan software supaya mendapatkan hasil yang maksimal. Perancangan hardware dibuat dalam bentuk blok diagram dan perancangan software dibuat dalam bentuk flowchart. Perancangan Sistem secara umum dapat ditunjukkan pada Gambar 1 berikut ini.

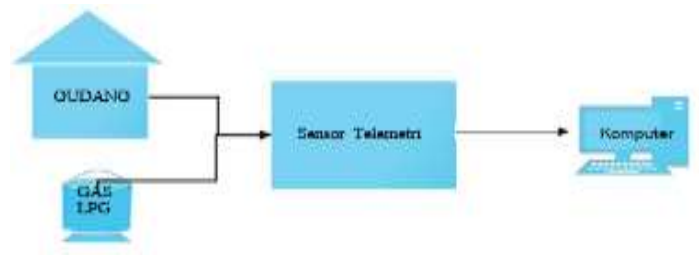

Gambar 1. Perancangan sistem secara umum

\subsection{Perancangan Perangkat Keras}

Perancangan hardware dalam penelitian telemetri sensor gudang gas LPG berbasis AT-Mega16 dapat ditunjukkan pada blok diagram pada Gambar 2.

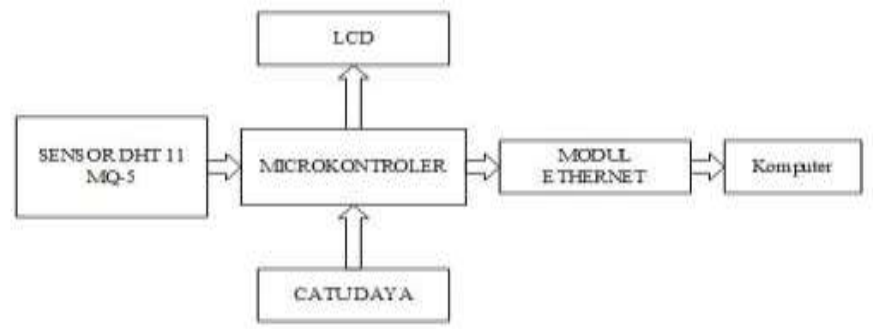

Gambar 2. Blok perancangan perangkat keras

Gambar 2 merupakan blok diagram telemetri sensor gudang LPG dimana sensor DHT-11 membaca suhu dan kelembaban, sensor MQ-5 membaca gas LPG, hasil pembacaan akan diolah mikrokotroler setelah itu mikrokontroler menampilkan hasil pembacaan sensor pada display LCD dan akan dikirim ke webserver dengan menggunakan module internet ENC28J60.

\subsection{Perancangan Perangkat Lunak}

Perancangan software ada tiga tahap, yaitu perancangan program mikrokontroler, pemprograman website, dan pembuatan database. Gambar 3 menunjukkan diagram alir.

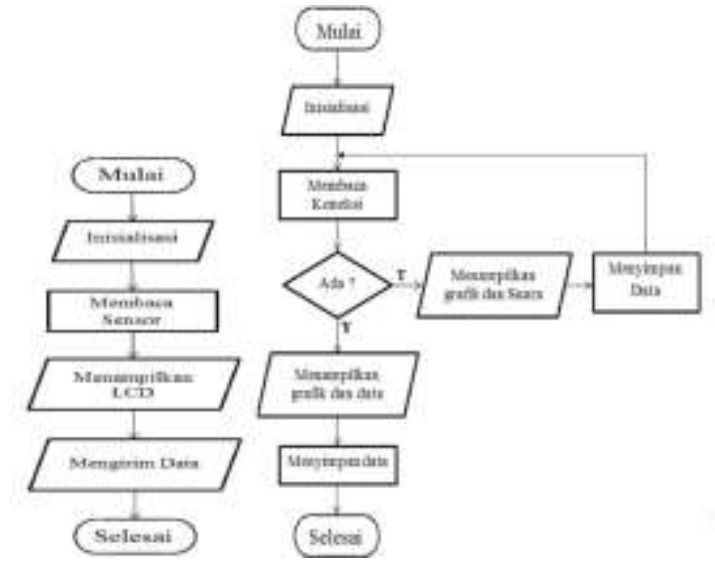

a b

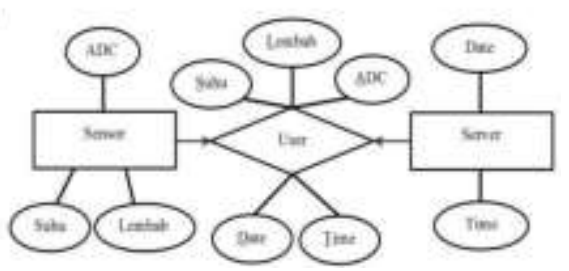

C

Gambar 3. Diagram alir (a) pemprograman mikrokontroler, (b) program website, (c) basis data 
Pemprograman mikrokontroler dirancang dengan flowchart seperti Gambar 3 (a). Pemprograman website menggunakan software notepad++ untuk menuliskan listing program, menggunakan browser untuk membuka halaman web yang sudah berisi program. Dalam memprogram website menggunakan HTML dan PHP, terdapat flowchart seperti Gambar 3 (b). Perancangan software yang terakhir adalah membangun database dengan membuat database pada software xampp. Perancangan database menggunakan flowchart seperti Gambar 3 (c).

\section{Hasil dan Pembahasan}

\subsection{Implementasi Sistem}

Implementasi merupakan tahapan setelah analisis dan perancangan sistem, dari implementasi dapat diketahui apakah alat yang telah dirancang dapat berjalan dan berfungsi dengan benar sehingga alat dapat menghasilkan output yang sesuai. Berikut penjelasan mengenai implementasi dari alat yang dibuat.

\subsubsection{Implesemtasi Pembacaan Sensor}

Pada proses pengambilan data sensor menggunakan beberapa obyek pengujian yaitu dengan gas untuk sensor gas MQ-5, es batu untuk suhu rendah dan hair dryer untuk suhu tinggi pada sensor DHT-11, dan dengan hembusan atau semprotan spray untuk kelembaban pada sensor DHT-11. Hasil pengujian sensor diperlukan Tabel untuk analisa. Hasil yang telah didapat dari pengujian disajikan dalam bentuk Tabel dan grafik. Tabel yang dibuat berdasarkan waktu seperti pada Tabel 1.

Tabel 1. Pengujian dengan gas

\begin{tabular}{cccc}
\hline Waktu/ & Gas & Suhu & Kelembaban \\
\hline menit & $($ Des $)$ & $\left({ }^{\circ} \mathrm{C}\right)$ & $(\%)$ \\
\hline 0 & 1 & 30 & 46 \\
\hline 1 & 2 & 31 & 45 \\
\hline 2 & 43 & 31 & 44 \\
\hline 3 & 57 & 31 & 42 \\
\hline 4 & 132 & 32 & 39 \\
\hline 5 & 241 & 32 & 37 \\
\hline 6 & 251 & 33 & 35 \\
\hline 7 & 251 & 33 & 35 \\
\hline 8 & 251 & 33 & 35 \\
\hline 9 & 251 & 33 & 35 \\
\hline 10 & 251 & 33 & 35 \\
\hline 11 & 251 & 33 & 35 \\
\hline 12 & 251 & 33 & 35 \\
\hline 13 & 251 & 33 & 35 \\
\hline 14 & 251 & 33 & 35 \\
\hline 15 & 251 & 33 & 35 \\
\hline 16 & 251 & 33 & 35 \\
\hline 17 & 251 & 33 & 35 \\
\hline 18 & 251 & 33 & 35 \\
\hline 19 & 251 & 33 & 35 \\
\hline 20 & 251 & 33 & \\
\hline & & & 35 \\
\hline
\end{tabular}

Berdasarkan Tabel 1 yang didapat dari pengujian dapat dianalisa tentang respon sensor MQ- 5 dalam pembacaan kebocoran gas. Waktu awal pengujian atau menit ke-0 nilai ADC yang terbaca sebesar 1 desimal, dalam pembacaan sensor MQ-5 menggunakan ADC 8 bit, sehingga nilai maksimal pembacaan adalah 251 desimal. Pada menit ke-0 nilai terbaca 1, maka dapat dihitung besar tegangan 
Jurnal IImu Teknik Elektro Komputer dan Informatika (JITEKI)

Vol. 2, No. 1, Juni2016

yang masuk pada $A D C$ dengan rumus $V=N i l a i A D C \times V f e r / 8$ bit. Sehingga tegangan masuk $=1 \times 5 /$ $255=0,0196$ volt, jadi tegangan output dari sensor atau tegangan yang masuk pada ADC sebesar 0,0196 volt.

\subsubsection{Pengujian Sensor dengan Es Batu}

Hasil pengujian sensor dibuat Tabel untuk analisa. Hasil yang telah didapat dari pengujian disajikan dalam bentuk tabel dan grafik. Tabel yang dibuat berdasarkan waktu seperti pada Tabel 2., maka dapat dipresentasikan dengan grafik pada Gambar 4.

Tabel 2. Pengujian dengan es batu

\begin{tabular}{crrc}
\hline Waktu/menit & $\begin{array}{c}\text { Gas } \\
(\text { ADC })\end{array}$ & Suhu $\left({ }^{\circ} \mathrm{C}\right)$ & Kelembaban $(\%)$ \\
\hline 0 & 1 & 33 & 80 \\
\hline 1 & 1 & 26 & 75 \\
\hline 2 & 1 & 24 & 69 \\
\hline 3 & 1 & 24 & 65 \\
\hline 4 & 1 & 23 & 61 \\
\hline 5 & 1 & 23 & 49 \\
\hline 6 & 1 & 23 & 43 \\
\hline 7 & 1 & 23 & 40 \\
\hline 8 & 1 & 23 & 39 \\
\hline 9 & 1 & 23 & 39 \\
\hline 10 & 1 & 23 & 39 \\
\hline 11 & 1 & 22 & 39 \\
\hline 12 & 1 & 22 & 39 \\
\hline 13 & 1 & 22 & 38 \\
\hline 14 & 1 & 21 & 38 \\
\hline 15 & 1 & 21 & 38 \\
\hline 16 & 1 & 21 & 38 \\
\hline 17 & 1 & 20 & 39 \\
\hline & & &
\end{tabular}

Hasil pembacaan sensor dapat dilihat pada Gambar 4 yaitu grafik yang menerangkan nilai data sensor terhadap waktu berupa nilai gas, suhu, dan kelembaban.

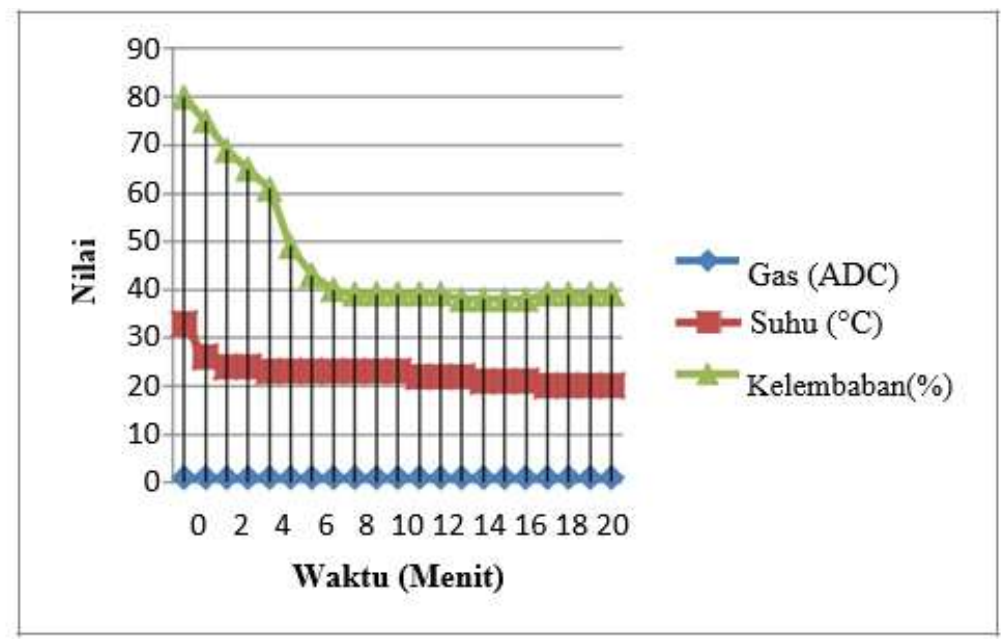

Gambar 4. Grafik pengujian dengan es batu 
Jurnal IImu Teknik Elektro Komputer dan Informatika (JITEKI)

Vol. 2, No. 1, Juni2016

\subsubsection{Pengujian Sensor Dengan Hair Dryer}

Hasil pengujian sensor dibuat Tabel untuk analisa. Hasil yang telah didapat dari pengujian disajikan dalam bentuk tabel dan grafik. Tabel yang dibuat berdasarkan waktu seperti pada Tabel 3 maka dapat dipresentasikan dengan grafik pada Gambar 5.

Tabel 3. Pengujian suhu menggunakan hair dryer

\begin{tabular}{|c|c|c|c|}
\hline Waktu/menit & $\begin{array}{c}\text { Gas } \\
\text { (ADC) }\end{array}$ & Suhu $\left({ }^{\circ} \mathrm{C}\right)$ & Kelembaban (\%) \\
\hline 0 & 1 & 32 & 35 \\
\hline 1 & 1 & 35 & 33 \\
\hline 2 & 1 & 38 & 31 \\
\hline 3 & 2 & 41 & 29 \\
\hline 4 & 2 & 42 & 29 \\
\hline 5 & 2 & 43 & 28 \\
\hline 6 & 2 & 45 & 27 \\
\hline 7 & 2 & 46 & 26 \\
\hline 8 & 2 & 47 & 25 \\
\hline 9 & 2 & 47 & 25 \\
\hline 10 & 2 & 49 & 24 \\
\hline 11 & 1 & 49 & 24 \\
\hline 12 & 2 & 49 & 24 \\
\hline 13 & 2 & 49 & 24 \\
\hline 14 & 1 & 51 & 23 \\
\hline 15 & 1 & 51 & 23 \\
\hline 16 & 1 & 51 & 23 \\
\hline 17 & 1 & 51 & 23 \\
\hline 18 & 1 & 51 & 23 \\
\hline 19 & 1 & 51 & 23 \\
\hline 20 & 1 & 51 & 23 \\
\hline
\end{tabular}

Hasil Tabel 3 diubah kedalam grafik pada Gambar 5 menerangkan nilai pembacaan gas, suhu, dan kelembaban terhadap waktu.

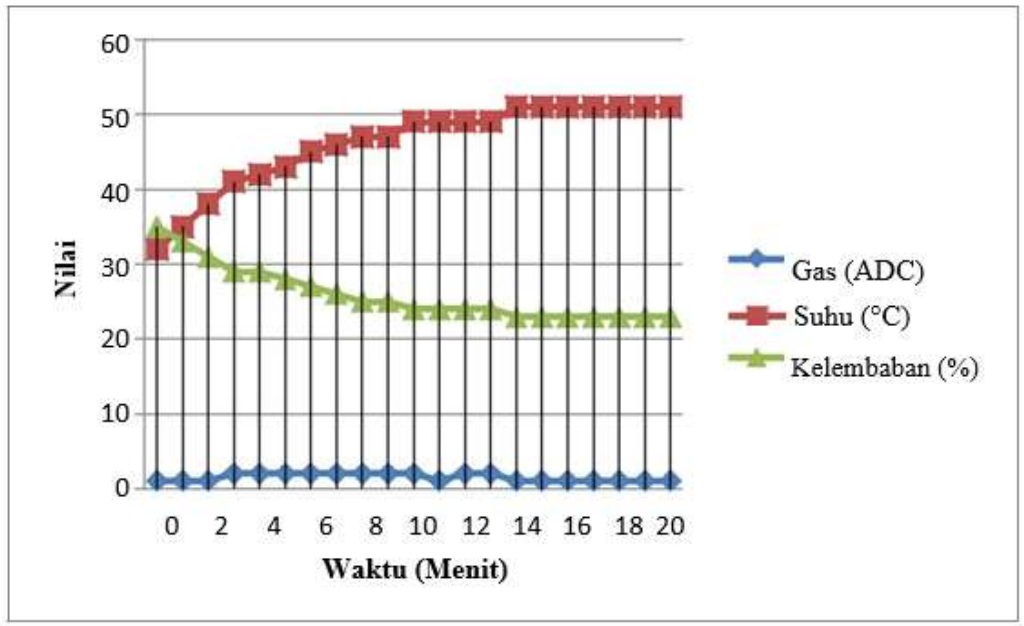

Gambar 5. Grafik pengujian dengan hair dryer 
Jurnal IImu Teknik Elektro Komputer dan Informatika (JITEKI)

Vol. 2, No. 1, Juni2016

\subsubsection{Pengujian Sensor dengan Spray}

Hasil pengujian sensor dibuat tabel untuk analisa, sehingga dapat dibuat grafik. Hasil yang telah didapat dari pengujian disajikan dalam bentuk tabel dan grafik. Tabel yang dibuat berdasarkan waktu seperti pada Tabel 4, maka tampilan grafik berdasarkan waktu pengujian yaitu permenit yang dipresentasikan dalam bentuk grafik pada Gambar 6 Pada pengujian ini membahas respon sensor kelembaban DHT-11 dengan membuat hembusan uap air dari spray.

Tabel 4. Pengujian Kelembaban menggunakan spray

\begin{tabular}{|c|c|c|c|}
\hline Waktu/menit & $\begin{array}{c}\text { Gas } \\
\text { (ADC) }\end{array}$ & Suhu $\left({ }^{\circ} \mathrm{C}\right)$ & Kelembaban (\%) \\
\hline 0 & 3 & 31 & 38 \\
\hline 1 & 3 & 29 & 84 \\
\hline 2 & 3 & 28 & 94 \\
\hline 3 & 3 & 28 & 96 \\
\hline 4 & 2 & 28 & 97 \\
\hline 5 & 2 & 28 & 97 \\
\hline 6 & 2 & 28 & 97 \\
\hline 7 & 2 & 28 & 97 \\
\hline 8 & 2 & 28 & 98 \\
\hline 9 & 2 & 28 & 98 \\
\hline 10 & 2 & 28 & 98 \\
\hline 11 & 2 & 27 & 98 \\
\hline 12 & 2 & 27 & 98 \\
\hline 13 & 2 & 26 & 99 \\
\hline 14 & 2 & 26 & 99 \\
\hline 15 & 2 & 26 & 99 \\
\hline 16 & 2 & 26 & 99 \\
\hline 17 & 2 & 26 & 99 \\
\hline 18 & 2 & 26 & 99 \\
\hline 19 & 2 & 26 & 99 \\
\hline 20 & 2 & 26 & 99 \\
\hline
\end{tabular}

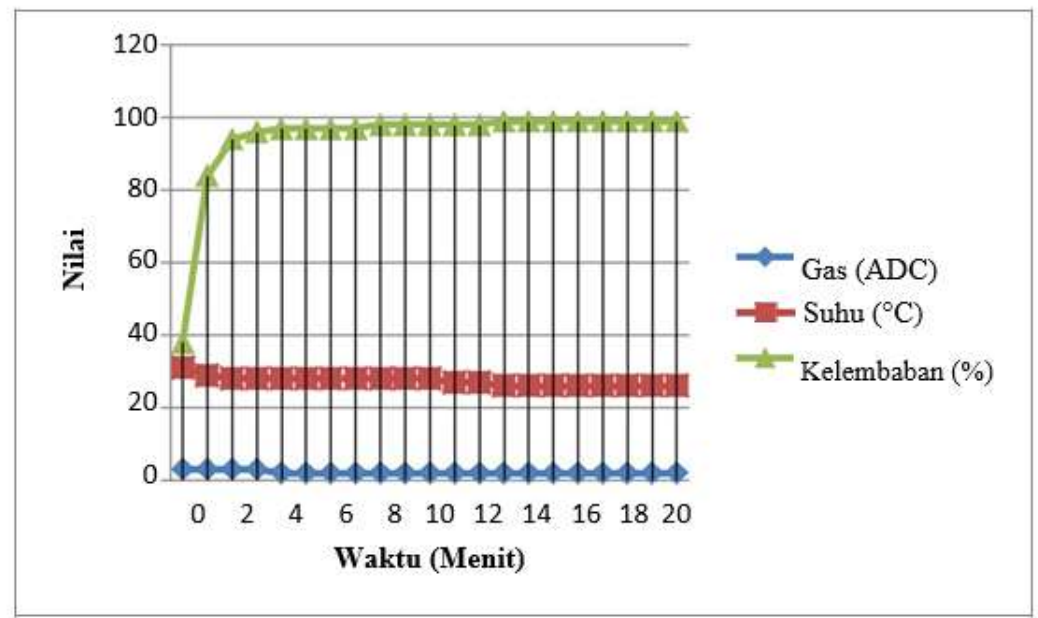

Gambar 6. Grafik Pengujian dengan spray 
Tabel 4 menerangkang hasil pembacaan sensor terhadap waktu seterti grafik pada Gambar 6 yaitu nilai gas dalam bentuk ADC, suhu dalam satuan celcius $\left({ }^{\circ} \mathrm{C}\right)$, dan kelembaban dalam satuan persen (\%).

\subsubsection{Implementasi Database}

Implementasi basis data ini merupakan hasil yang disimpan pada database, yang hasilnya dapat dilaporkan sesuai pilihan. Pilihan pelaporan dibuat pelaporan status, pelaporan harian, pelaporan bulanan, dan pelaporan keseluruhan.

\subsubsection{Laporan Status}

Sistem pelaporan status akan menampilkan hasil status yang dipilih. Jika pilihan status adalah "connect" maka hasil yang akan dilaporkan adalah data pada status "connect" semua. Pada pilihan status "no connect" maka hasil yang akan dilaporkan adalah data pada status "no connect" semua. Hasil pelaporan pada status "connect" seperti pada Gambar 7.

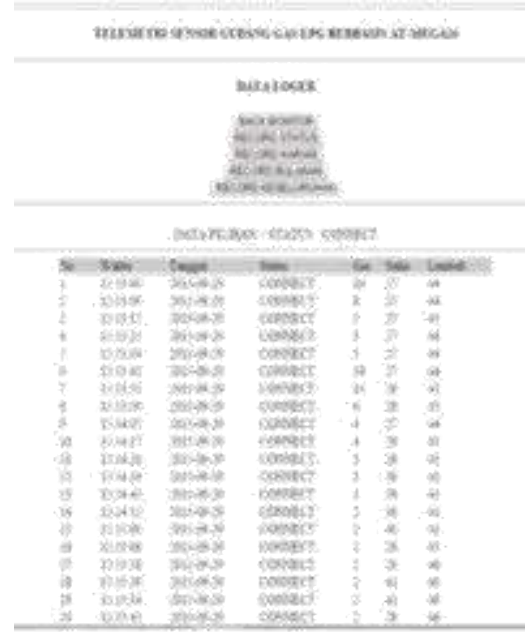

Gambar 7. Tampilan laporan status connect

Hasil pada Gambar 7 diatas hanya menunjukkan laporan yang dipilih yaitu pada status connect.

\subsubsection{Laporan dalam Website}

Sistem pelaporan harian, bulanan, dan tahunan akan menampilkan hasil penampilan data yang dipilih pada tanggal atau hari yang dipilih. Jika pilihan pada halaman pelaporan dipilih contoh pada 01 JANUARI-2015 seperti pada Gambar 8.

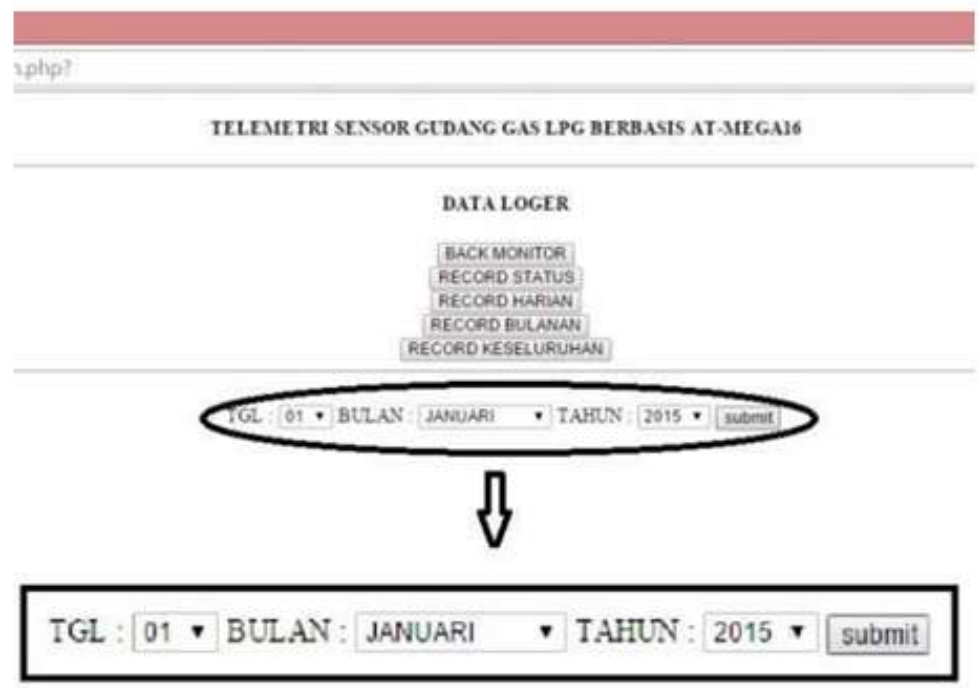

Gambar 8. Pilihan masukan laporan 
Gambar 8 menunjukan hasil setelah di submit pada masukan pilihan diatas adalah tanggal 01 bulan januari tahun 2015 sehingga akan memberikan laporan harian, bulanan dan tahunan.

\section{Kesimpulan}

Penelitian yang dilakukan ini menghasilkan sebuah implementasi yang dapat disimpulkan sebagai berikut:

1. Hasil pengujian gas yang dilakukan, respon sensor $M Q-5$ dapat merespon gas dengan nilai terkecil pada ADC adalah sebesar 1 desimal, tegangan yang masuk sebesar $0.02 \mathrm{~V}$, dan pada saat ada gas yang terbaca dapat membaca paling besar atau nilai maksimal yaitu sebesar 255 desimal, maka tegangan yang dibaca adalah sebesar $5 \mathrm{~V}$.

2. Hasil pengujian suhu yang dilakukan, respon sensor DHT-11 dapat merespon suhu es batu dua buah tidak kontak dengan es batu secara langsung adalah pada menit ke-17 yaitu $20^{\circ} \mathrm{C}$, maka pada menit tersebut sensor hanya membaca sebesar $20^{\circ} \mathrm{C}$. Pengujian dengan hair dryer respon sensor DHT-11 dapat merespon suhu tinggi dengan nilai paling besar atau maksimal pada menit ke-14 yaitu sebesar $51^{\circ} \mathrm{C}$. Range sensor DHT-11 pada pengujian ini dapat merespon $20^{\circ} \mathrm{C}$ sampai $51^{\circ} \mathrm{C}$.

3. Hasil pengujian kelembaban yang dilakukan, sensor DHT-11 dapat merespon kelembaban pada ruang terbuka normal sekitar $38 \%$ dan pada saat pengujian dengan spray dapat merespon dengan nilai paling besar atau maksimal pada menit ke-13 yaitu sebesar $99 \%$ kelembaban. Sistem basis data yang dibuat dapat melaporkan dengan laporan status koneksi, laporan harian, laporan bulanan, dan laporan keseluruhan data.

\section{Referensi}

[1] A. Saefullah, H. Syahrial, and A. Santoso, "Pendeteksi Kebocoran Tabung Gas Lpg Menggunakan Mikrokontroller At89S2051 Melalui Handphone Sebagai Media Informasi," vol. 2012, no. Semantik, pp. 18-25, 2012.

[2] Sukri, "Perancangan Alat Pendeteksi Kebocoran Gas pada Tabung LPG menggunakan Sensor TGS 2610," Ahmad Dahlan, 2010.

[3] B. D. Danuar, "Sistem Pendeteksian Kebocoran Gas LPG Menggunakan Mikrokontroler," Univ. Andalas, Padang, vol. 2013, 2013.

[4] P. D. T. E. S. V. Mutiara Vidyasanti and U. G. M. Y. 2013, "TELEMETRI SUHU DAN GAS BERBASIS MIKROKONTROLER ATMEGA 16," Progr. DIPLOMA Tek. ELEKTRO Sekol. VOKASI Univ. GADJAH MADA YOGYAKARTA, p. 308605, 2013.

[5] F. E. dan K. I. T. B. Manik Alit Wastharini, Dharu Arseno. Ir.MT, Iswahyudi Hidayat. ST.MT, "( DESIGN AND IMPLEMENTATION OF TELEMETRY SYSTEM FOR ROOM TEMPERATURE BASED ON," Fak. Elekro dan Komun. IT Telkom Bandung, 2010.

[6] M. A. Novianta et al., "TELEMETRI SUHU SECARA REALTIME BERBASIS ASK-FM DENGAN PEMPROGRAMAN VISUAL BASIC REALTIMELY TEMPERATUR TELEMETRY BASE ON ASK-FM Abstrak D-1 Prosiding Seminar Nasional Teknoin 2010 Bidang Teknik Elektro Metodologi Penelitian D-2," pp. 978-979, 2010.

[7] Agus Bejo (2008), C \& AVR Rahasia kemudahan bahasa C dalam mikrokontroler ATMEGA 8535, Pertama. Yogyakarta: Graha IImu, 2008.

[8] U. M. Ary Heryanto, S.T, Ir. Wisnu Adi P., Pemrograman Bahasa C untuk Mikrokontroler Atmega 8535, Ed.1.-Yogy. Yogyakarta: ANDI, 2008.

[9] Vishay, "LCD 2X16," 2002. [Online]. Available: http://www.alldatasheet.com/datasheetpdf/pdf/251973/VISHAY/LCD-016M002L.html. [Accessed: 02-Dec-2012].

[10] L. Hakim, Jalan pintas menjadi master PHP. Yogyakarta: Penerbit Lokomedia, 2009.

[11] w3schools, "PHP 5 Tutorial," http://www.w3schools.com/php/default.asp. [Online]. Available: http://www.w3schools.com/php/default.asp. [Accessed: 14-Apr-2015]. 